\title{
Semantic Restrictions of Forming Derivative Nouns in the Class of the Process Verbs
}

\author{
Liliya Ponomaryova \\ Oles Honchar Dnipropetrovsk National University, Ukraine \\ E-mail: lilienp@gmail.com
}

\begin{abstract}
Keywords: word formation, restrictions in word formation, types of semantic restrictions, word forming powers of process verbs.
\end{abstract}

\begin{abstract}
Studying structural, phono-morphological, semantic, stylistic, word-forming and lexical conformities regulating syntagmatic connections in word-formation, requires studying system restrictions of the word-forming morphemes combinability, predetermined by the meaning of a word sign as well. The aim of the article is to identify semantic restrictions and those close to them in forming deverbative nouns from the process verbs. It was defined that such kinds of restrictions as semantic, semantic-pragmatic, semantic-stylistic, lexical and structural-morphological can counteract the possibility of the process verbs to take part in derivation processes. Semantic restrictions are located at the level of syntagmatic, differentiating semes and the abstract subcategory seme "becoming". Aspect semes don't influence the possibility of the process verbs to take part in the word formation processes. Semantic restrictions can be predetermined both by the presence and by the absence of definite semes in a semantic structure of a word.
\end{abstract}

\section{Introduction}

While investigating the content aspect of language units in modern linguistics, significant attention is paid to the problem of semantic restrictions in different language areas. Identifying semantic limits and restrictions of word-building morphemes combinability and their typical representation is a constituent of the research aimed at both studying the general problem of word formation development and developing the theory of the linguistic probability in reference to word formation.

Restrictions in the morpheme combinability are considered either as a separate aspect of linguistic research (Y. Zemskaya [1, p.195], I. Ulukhanov [2, pp.214-243], H. Neuhaus [3], B. Hansen [4] and F. Plank [5]), or as a compulsory constituent of a general problem of word-forming morphemes combinability (Y. Kubryakova [6, pp.207-219] and M. Stepanova [7, p.156]), or are included in the concept of word-forming rules (restriction rules or blocking rules) (J. Erben [8, p.35], W. Fleischer [9], I. Barz [10, pp.56-57], E. Clark [11, p.789], D. Kastowsky [12], W. Motsch [13, p.113], J. Rose [14].

Semantic restrictions in word formation are one of the kinds of semantic combinability restrictions of the word-building morphemes which are conditioned by the meaning of a word sign, the essential feature of which is the lack of the semantic agreement between the constituents of a formed word. The common feature of both combinability of word-building morphemes and restrictions in combining the elements of the formed words is that any morpheme can not freely combine with any other morpheme [1, p.35]. Studying structural phono-morphological, wordbuilding and lexical conformities regulating the syntagmatic connections in this language area, which imply "the connection of word-building formants with the motivation basis within the motivated word", is closely connected with studying the systematic combinability restrictions of the word-building morphemes conditioned by a meaning of a word sign [2, p.14; 3, pp.79-80].

The aim of the article is to identify semantic and contiguous with them restrictions in forming deverbative nouns from the process words. The aim of the research determines the problems that should be solved: 1) to establish the circle of the productive and non-productive verbal lexis; 2) to define the role of the semantic restrictions as a constituent of the semantic combinability restrictions of word-building morphemes; 3) to separate the semantic restrictions from other types of 
combinability restrictions of word-building morphemes; 4) to establish the possibility and conditions of neutralizing the semantic and other kinds of restrictions.

\section{Theory}

In the scientific works dealing with the problem of system conformities of word-building morphemes, semantic restrictions are defined as incompatibility of a derivation morpheme and a productive base [1, p.194; 2, p.177; 6, pp.218-220; 7, p.218; 8, p.43; 12, p.161, 13, p.114]. A certain quality of word-forming morphemes [2, p.215] or correspondent semes lie in the basis of the semantic coordination [7, p.161]. As the composition and denoting of the system restrictions and conformities of joining word-building morphemes are classified by linguistic researchers in different ways: semantic, lexical, stylistic, pragmatic, word-forming, etymological, phonological, morphological, syntactical and non-syntactical (pragmatic), the classification of Y. Zemskaya [1, pp.195-204] which has much in common with the restriction classification suggested by $\mathrm{V}$. Fleischer and I. Barz [10, p.56], is accepted as the basic one in this work.

With the aim of analyzing the verb base and detecting the possibilities or impossibilities of their participating in the derivative process as well as establishing the restrictions blocking these possibilities, we applied the classification of $\mathrm{H}$. Brinkman which is relevant for both syntagmatic and paradigmatic and includes the process verbs [15, p.122].The process verbs denote internal and external changes of a subject in time and space, its vital activities and functioning. The material for the research included simple German verbs taken from E. Matter's dictionary [16, pp.9-31].

The verbs which denote movements, changes of the state, physiological processes, sounds and food taking can be referred to the class of the process verbs. They are mainly one-valence verbs with one optional (adverbial) valence. The semantic structure of transitive verbs denoting food taking contains the syntagmatic seme of the action object. The majority of the verbs denoting secretion and some verbs denoting physiological processes and changes of the state have the verb lexical base explicitly expressed by the seme of the object of action (speicheln, eitern, köpfen, rosten, ferkeln, kalben etc.), so they are characterized by the presence of the inner object.

The semantic structure of the verbs included in the lexical seme of the verb (LSV), possesses a various degree of complexity. Thus, the verbs of the LSV denoting the change of the state contains not only corresponding syntagmatic, gender and differential semes, but also the abstract sub-category seme of "becoming" which denotes the internal development and internal movement as a result of self-development or self-movement or development under the influence of an external force [17, p.16]. The composition of the differentiating semes of the verbs is ranging from one to three, the more split up classification is also possible. The typical word-forming paradigm (TWP) of the process verbs is represented by nomen agentis, nomen subjekti, nomen actionis, nomen instrumenti, nomen loci, nomen quanti as well as nomen objekti and nomen resultatis (certain formations).

The possibility of forming the derivative names of a person is conditioned by the presence in the grammatical structure of the process verbs of implicit seme "person" and, correspondently, its lack blocks up the formation of the derivatives with the above-mentioned semantics. Incompatibility of the verb semantics and the suffix semantics excludes from the productive base of the verbs of secretion a large group of motion verbs: sacken, ranken, sprudeln, sickern, münden; the verbs of changing the state allowing in the subjective position the nouns denoting the objects of animate and inanimate nature: trocknen, schmelzen, platzen, bräunen; a part of verbs denoting physiological process that are related to the representatives of the animal world: hecken, schmutzen,laichen; a significant part of the verbs with the LSV of sounds, characterizing the sounds made by animate creatures (excluding humans): bellen, mecken, heulen, quacken and made by inanimate subjects: rascheln, knistern, knacken, krachen. The presence of the seme "person" is a necessary but not always the only sufficient component of the verb semantic structure, because there are no derivative names from many verbs meeting the first condition. 


\section{Results}

Studying and comparing the semantic structure of the verbs of motion allows us to get the results that all semantic restrictions, (except for the mentioned above) are caused by the two-fold factors: 1) explicit expression of the seme "person" by the lexical base of a verb (pilgern, tölpeln, zigeunern) and 2) a range of differentiating semes, such as «termination» (kommen), «involuntariness» (kommen, stürzen, zittern, zucken), «comparability» (storchen, wirbeln, geistern), as well as the seme «multitude» (wimmeln, wieben, kribbeln) distinguished in the verbs referring to the group.

The formation of the agentive derivatives from the verbs with LSV of changing the state with the seme "change of the physical state of a person" (kranken, heilen, älteln, sterben) is opposed by the abstract subcategory seme "becoming" blocking up the formations like Reifer ${ }^{\circ}$, Heiler ${ }^{\circ}$ as well as the differentiating seme "termination" (Sterber ${ }^{\circ}$.

"Mene" of the semantic category of the subject of action leads to forming the meaning with the modal sign [18, p.165] and in this case the verbs with LSV of sounds not containing the seme "person" in its semantic structure, but combining with an animate subject can become a basis for forming the names of a person with a definite pragmatic direction: Beller ${ }^{\circ}$, Jaulerin ${ }^{\circ}$.

For codified literary language it is not characteristic to form the name of a person from the verbs of LSV of physiological processes in spite of the fact that seme "person" is implicitly present in the semantic structure of the verbs (Schnarcher). Non-realization of word-forming possibilities is evidently connected with the lack of communicative needs in forming the nominative units with the given meaning from the verbs of the given LSV and/or the lack of the text necessity of their appearance. In case of necessity, they can be formed with the aim giving the negative characteristic of a person: Rotzer ${ }^{\circ}$, Hüstling ${ }^{\circ}$.

Lexical restrictions along with the semantic restrictions play a definite role. They are connected with the competitive nature of the word-building patterns, above all, substantivized Participle I (der Reisende), as well as with the realization of the other meanings of a verb lexeme in the derivation processes (Wipper, Weber, Streicher). The presence in the language lexical system of a word with a different meaning homonymous to the one which could have been derived prevents the appearance of the derivative names of a person from the range of verbs motivated by nouns which served as the basis for forming the names of person with other meaning: Türmer, Bader, Seiler, Nicker.

The derivatives formed by the same derivation pattern but having different meanings, like Jodler - Jodelruf, Jodelgesang; der jodelt (Wahrig), are considered in this research as the facts of regular polysemy connected with the polyfunction of the suffix - er [9, p.141], though some other points of view exist. That's why the lack of derivatives of names of person from some verbs that serve as the basis for forming the names of action, for example, Jauchzer - Jubelruf can not be considered as a lexical restriction.

Forming abstract nouns from the verbs of this class follows the pattern: «verb base + ung», «verb base + ei» and «verb base + er». The last pattern serves for forming derivatives with the meaning of a certain action.

Having the common meaning segment, the patterns «verb base + ung», «verb base + ei» can be considered to be competitive as they are used for forming derivatives, conveying the meaning of a process or a state, expressed by the verb base. However, their semantics has both common and specific features and their meanings do not coincide completely. Besides, both patterns are applied in different circles of productive bases.

\section{Discussion}

The derivatives ending in -ung, their semantics and syntax have often been the object of investigation of Germanic linguists. The analysis of the works that dealt with the attempt to identify the closed verb groups as well as the results of the present investigation, gives grounds to agree with the opinion of T. Schippan that it is impossible to establish such closed thematic groups of verbs, as 
the derivatives ending in -ung can either be formed or can not be formed in the same groups [19, p.167; 20, pp.310-312;21;22, pp.210-212;23]. As the analysis of the factual material showed (continuous selection from the dictionary «Duden Deutsches Universalwörterbuch») the current vocabulary of the German language contains 6542 nouns formed by this model. Non-prefix derivatives account for 732 [23, p.311]. This proves the frequency of the model which was mentioned in many works.

Abstract derivatives ending in - ung are found in all the verbs with the LSG of the process (Steigerung, Reifung, Blähung, Zehrung, Eiterung) besides the LSG of sounds, the lack of derivatives of which are also noticed by other authors [20; p.311]. However, it doesn't seem possible to distinguish as a reason for this situation any other component in the semantic structure not only of the verbs denoting sounds but also of the other verbs of this model that don't take part in derivation process. The lack of derivatives ending in - ung of the verbs denoting sounds are likely to have been caused not by the factors of purely semantic character, but can be explained by the action of other kinds of restriction: semantic-stylistic, lexical and structural- morphological. Semantic-stylistic restrictions block the formation of the derivatives ending in -ung from stylistically marked verbs (flennen, plärren, grölen). The structural-morphological restrictions block up forming derivatives from the verbs ending in -eln (rascheln, säusen, murmeln). This kind of restrictions often adjoins semantic-lexical restrictions (bimmeln, bammeln).

Lexical restrictions are expressed as a rivalry of the word-forming models, above all those of the substantivized infinitive (Schellen, Weinen, lachen, Rauschen, Knattern). As it is emphasized, the substantivized infinitive from the verb denoting sounds is often used in terminology (das Summen - zummer; das Pfeifen - radiowhistle; das Klingeln - microphone effect of sounds; das Donnern - howling) [24, p.52] and easily appears in a text to denote the process of action itself [25, pp.102-104].

As a rivaling model, the models «VB+ ei and ge + VB (das Geknister, das Geknirsche, das Gerassel; das Gekrach; die Klimperei; die Schnatterei) can be considered, but these models convey, first of all, the meaning of a continuous (Knallerei, Geklimper, Geplärr) or continuous annoying process (Huperei, Gegacker).

These kinds of restrictions are also characteristic for other LSV of the process verbs. The exclusion is the group of verbs denoting the change of state, in the semantic structure of which there is no seme "assessment' and which don't have any restrictions.

As it was noted, the model "VB + ei" is used for forming derivatives with the meaning of substantivized action. There is no definite opinion as for the range of this model. No doubt, there is a tendency to form abstract nouns from the verbs which are stylistically marked using the model «VB+ei»: Zottelei,Flennerei, Sauferei.

The lack of derivatives ending in -ei with the meaning of the action process from the group of the verbs with the LSV of secretion, which doesn't include stylistically marked verbs can be explained by this tendency. However, as derivatives ending in -ei are formed from the stylistically neutral verbs, (Taumelei, Hupperei, Treterei, Trinkerei, Lacherei, Summerei) it can mean that it's possible to speak about a certain tendency but not about the rule.

Emphasizing a special ability of this model to form the abstract nouns from the verbs denoting sound due to its "intensive" meaning, R. Kurt points out that it can not be used if we mean the verbs that characterize sounds made by inanimate objects. It is explained by the fact that the semantics of the given model conveys not only the repetition of actions, but also their being annoying and irritating, in other words, the negative assessment of the action, and this approach is not applicable to natural usual noises [20, p.311].

This point of view doesn't seem persuasive enough for the following reasons. Firstly, the verbs denoting the sounds made by objects are included by other researchers to the group of the productive bases, for example, bimmeln, bammeln, rascheln, prasseln [15, p.30]. Secondly, it's necessary to prioritize not the verb semantic, but that of the model. Possibly, if we gave the model «VB+ ei» the meaning or the variant of a semantic meaning not only of process [15, p.118], but a continuous and annoying one, it would be possible to avoid the attempts to identify a special circle 
of bases that take part or don't take part in the noun-formation by the given model. The possibility of forming derivatives with the meaning of continuous and irritating process depends on the position of a nominative subject, as any sound can cause the feeling of annoyance and called correspondently. Occasional derivatives may denote a continuous and repeated process: Summerei, Klopferei. Besides the meaning of a definite process, the derivatives formed by the model «VB + ei» can have the meaning of continuous annoying process. Both the verbs referring to stylistically marked and stylistically neutral lexis layer (Fahrerei, Schreierei, Sabberei) can be the productive basis. The tendency of forming nouns with this semantics from stylistically neutral verbs should be underlined: Springerei, Schwimmerei, Tänzerei, Gespensterei.

The semantic restrictions block up forming derivatives ending in -ei from the verbs with the LSV of changing the state which contain the differential seme "termination": Sterberei, Bersterei ${ }^{\circ}$. While splitting the motion process into separate acts facilitates forming derivatives ending in -ei, the continuity, limitlessness and indivision in time which is characteristic for the verbs of gradual motion, denoting the water mass movements (fließen, rinnen, rieseln, strömen), prevents the derivatives by the model «VB + ei» from appearing. It can be considered as semantic restrictions as the discreet quantity can characterize only those objects that have the class discontinuity.

The lack of derivatives ending in -ei from the verbs of high stylistic tone can be considered as a semantic-stylistic restriction. These verbs include poetic, archaic and bookish words, while the verbs of the lowered stylistic tone and the neutral tone, as it was mentioned before, can form similar derivatives: essen-Esserei, but speisen - ${ }^{\circ}$ Speiserei; flennen - Flennerei, but greinen - ${ }^{\circ}$ Greinerei.

Lexical restrictions are expressed in the rivalry of the word-forming model «VB + ei» with the model «ge $+\mathrm{VB}$ » with the meaning of the continual action (Geplärr, Gegrunze, Geseufze, Geröchel).

Structural-morphological restrictions come from deajective verbs which are represented especially widely in LSG of the verbs denoting changing of state [21, p.219], as well as in other LSV (runden, lahmen). However, it should be mentioned that derivatives from the verbs of the given type can be found (Tollerei).

The derivatives with the meaning of a separate action (nomina quanti) is formed by several word-forming models, first of all, the model «VB + er», which is considered in this research as the basic one, while forming derivatives with the meaning of action quant by other models (Fall, Sturz, Plumps, Grätsche, Sprung, Schwingung) can be seen as the fact of lexical restrictions. The formation of the derivatives with this semantic is blocked by the meaning of a single act explicitly expressed by lexical verb base.

Noun word formation of above mentioned semantics is characteristic for the verbs with the LSV of movements, physiological processes and sounds, in other words, motor verbs having the differential seme "interativeness": Hüpfer, Hopser, Rumpler, Seufzer, Hichser, Schnaufer, Knurrer, Brüller, Taucher, Barmer u.a. The lack of the seme "interatiness" in the semantic structure of the verbs prevents forming derivatives with the meaning "action - action amount".

In dictionary definitions of such verbs as wiebeln, wimmeln, kribbeln - viele winzige Bewegungen zeigen there is an indication of the action amount which can be considered as a semantic restriction also preventing derivative forming with the meaning of action quant. The derivative Bewegung in the meaning "a separate movement" is a common name for them. The meaning of a separate action is reflected in the dictionary definitions of many other verbs, for example, laufen - sich mit schnellen Schritten fortbewegen, as well as the verbs explained by the verb laufen (prellen, rennen, hasten, asten, wetzen, tippeln).

There are no derivatives with the same semantics from the majority of onomatopoetic verbs (gicksen, kichern, prusten, glucksen, klingeln, bimmeln, bammeln, ticken, tacken etc.) which imitate non-speech sounds. The source of these sounds is noises or the sounds of the reality which can be expressed by words [26, p.77]. It can be assumed, that splitting of the acoustic sound which is conveyed by exclamations in the base of sound imitating verbs (kichern - leise, in kurzen Tönen lachen), prevents forming derivatives with the meaning of a single action. However, there are such derivatives from some verbs - Mucks, Klicks, which gives grounds to refer such restrictions to lexical ones. 
Semantic restrictions block up forming derivatives with the meaning "quant of an action" from desubstantial verbs, the lexical base of which expresses a single sound act or their combination (trillern, knallen).

Forming derivatives with the meaning of the subject of action is not characteristic for process verbs. The derivatives referring to the subject paradigm are not numerous and they mean inanimate objects or representatives of the animal world which possess the quality expressed by a wordbuilding base, for example, Pieper - ein kleines Gerät, das piept, wenn es ein Funksignal empfängt; Läufer, Schwimmer, Hupfer -Adam's apple; Krächzer-crow.

Semantic restrictions in forming nomen subjekti are characteristic for all the verbs, in the semantic structure of which there is the seme "person".

Semantic-pragmatic restrictions block up forming the object names from the verbs with the specialized action subject, for example, schwappen, schwappern - Flüssigkeiten, kreisen - Blut (LSV of motion verbs) [27, p.131].

Taking into consideration the fact that animal names belong to subjective paradigm (Der Hund kläfft - Kläffer), the animal names as well as the names of the concrete objects (Sauser) can be referred to the category nomen subjekti [21, p.337].

The possibilities of realizing potential abilities of process verbs with the seme "sounds" made by animate creature (except for humans) defines the connection with the specialized action subject. The lack of derivatives from such verbs as miauen - Katze, wiechern - Pferd can be considered as lexical-pragmatic restrictions..

Lexical restrictions are connected with occupying a certain lexical place by person names formed from the figurative meanings of the verb (Winseler, Meckerer), however, very often the tendency for preserving the communicative distinction of lexical units is not observed: Krächzer Rabe, Krähe, Person. Lexical restrictions are found in the competition of the word-forming models and the presence of homonymic models and homonymic nouns [27, p.132].

\section{Conclusions}

Thus, the possibilities of process verbs participating in derivation can be resisted by the following kinds of restrictions: semantic, semantic-pragmatic, semantic stylistic, lexical and structural-morphological. Semantic restrictions are located on the level of syntagmatic, differential semes and the abstract subcategory seme "becoming". The semes of the kind do not influence the possibility of the process verbs to take part in the processes of word-formation. The absence of the necessity of forming derivatives from the part of the process verbs can be considered as semanticpragmatic restrictions. Lexical restrictions connected with the occupation of the given lexical location take a special place.

\section{References}

[1] Y.A. Zemskaya, Modern Russian language. Word formation, Prosveshcheniye, Moskow, USSR, 1973.

[2] I.S. Ulukhanov, Word-building semantics in Russian and the principles of its description, Editorial, Moskow, Russian Federation, 2001.

[3] H.J. Neuhaus, Wortbildung und Semantik, in: Perspektiven der Wortbildungsforschung, Bonn, Germany, 1977, pp. 203-209.

[4] B. Hansen, K. Hansen, A. Neubert, M. Schentke, Englische Lexikologie. Einführung in die Wortbildung und lexische Semantik, VEB Verlag Enzyklopädie, Leipzig, Germany, 1982.

[5] F. Plank, Morphologische Irregularitäten. Aspekte der Wortstrukturtheorie, Tübingen, Narr, Germany, 1981.

[6] Y.S. Kubryakova, Z.A. Kharitonchik, On word building significance and description of the semantic structure of derivatives of the suffix type, Moskow, USSR, 1976, pp. 292-233.

[7] M.D. Stepanowa, W. Fleischer, Grundzüge der deutschen Wortbildung, VEB Bibliographisches Institut, Leipzig, Germany, 1985. 
[8] J. Erben, Einführung in die deutsche Wortbildungslehre, in: Grundlagen der Germanistik, v. 17, Erich Schmidt, Berlin, Germany, 2006.

[9] W.Fleischer, Regeln der Wortbildung und Wortverwendung, in: Deutsch als Fremdsprache, 1978, pp. 78-85.

[10] W. Fleischer, I. Barz, Wortbildung der deutschen Gegenwartssprache, Niemeyer Verlag GmbH, Tübingen, Germany, 2007.

[11] E.V. Clark, H.H. Clark, When Nouns Surface as Verbs, Language, 55:4, (1979) 767-811.

[12] D. Kastowsky, Wortbildung und Semantik, Pädagogischer Verlag Schwann, Düsseldorf, Germany, 1982.

[13] W. Motsch, Deutsche Wortbildung in Grundzügen, in: Schriften des Instituts für deutsche Sprache; 8, Walter de Gruyter, Berlin/New York, 2004.

[14] J.H. Rose, Principle Limitations on Productivity in Denominal Verbs, Foundation of Language, 10:4 (1973) 509-526.

[15] H. Brinkmann, Die Wortarten im Deutschen, in: Das Ringen um eine neue deutsche Grammatik, Darmstadt, Germany, 1965, pp. 101-127.

[16] E. Mater, Deutsche Verben. Bd. 3, VEB Bibliographisches Institut, Leipzig, Germany, 1967.

[17] R.M. Gaisina, Meaning and syntagmatics of verbs (relation verbs as an example), Vyshchaya shkola, Moskow, USSR, 1986.

[18] A.A. Ufimtseva, Lexical meaning: the principle of semiological lexis description, Nauka, Moskow, USSR, 1986.

[19] W. Fleischer, Wortbildung der deutschen Gegenwartssprache, VEB Bibliographisches Institut, Leipzig, Germany, 1983.

[20] R. Kurth, Über den Gebrauch der Bildungen auf und Gebrauch der Wörter auf -ei, -erei, -elei, in: Beiträge zur Geschichte der deutschen Sprache und Literatur, Halle (Saale), Germany, 1956, bd. 78, pp. 307-316.

[21] Th. Schippan, Die Verbalsubstantive in der deutschen Sprache der Gegenwart, in: Deutschunterricht, H. 9, 1968, pp. 516-526.

[22] H. Wellmann, Das Substantiv, Pädagogischer Verlag Schwann, Düsseldorf, Germany, 1975.

[23] N.B. Pimenova, Semantische Restriktionen für die unga-Ableitung im Althochdeutschen, Germanistisches Jahrbuch der GUS „Das Wort“. (2002) 93-106.

[24] N.A. Dementyeva, Comparative and semantic analysis of the verbs of sound in German and Russian, Moskow, USSR, 1982.

[25] M.D. Stepanova, Word formation of the modern German language, Publishing house of literature in foreign languages, Moskow, USSR, 1953.

[26] Y.A. Glukhareva, Sound imitating verbs with dissonant denotant (semantic peculiarities), Tula, 1976, pp. 77-94.

[27] L.F. Ponomaryova, Semantic restrictions in forming deverbative derivatives with the meaning of subject, Bulletin of the Dnipropetrovsk University, series Language studies. 22:11 (2014) 127-133. 